\title{
A Postharvest Dip Treatment with Lysophosphatidylethanolamine, a Natural Phospholipid, May Retard Senescence and Improve the Shelf Life of Banana Fruit
}

\author{
Zienab F.R. Ahmed \\ Department of Horticulture, South Valley University, Qena 83523, Egypt
}

Jiwan P. Palta ${ }^{1}$

Department of Horticulture, University of Wisconsin-Madison, 1575 Linden

Drive, Madison, WI 53706

Additional index words. banana, lysophosphatidylethanolamine, LPE, shelf life, fruit ripening, senescence, membrane leakage, fruit respiration, fruit firmness

\begin{abstract}
Banana is one of the most consumed tropical fruits around the world. It is marketed nearly all year-around and has a relatively short shelf life. Fruits are harvested mature green and treated with ethylene to stimulate ripening before distribution and sale. The fruits generally ripen within 4-5 days after ethylene treatment and sold primarily at yellow stage of ripening. After turning yellow the fruit becomes unsuitable for marketing in 1-3 days. Thus 1-2 days of improvement in the fruit shelf life could enhance the market value of banana. Previous studies conducted in our laboratory have demonstrated that both pre- and postharvest application of lysophosphatidylethanolamine (LPE) can retard aging and improve shelf life of various fruits. The objective of this study was to investigate the possibility of improving shelf life of banana fruit by a postharvest dip in LPE. For this purpose, whole fruits obtained from the market at ripeness stage of 2.5 (about $75 \%$ green) were dipped in solution of $500 \mathrm{ppm}$ LPE for 30 minutes and observed for a period of five days at room temperature. Each treatment was applied to 50 uniform fruits. From each hand bought, an equal number of fruits were separated for LPE and control treatments to reduce the variability. Five days after dip treatment, the fruit treated with LPE were firmer and thicker as compared with the control. Starch breakdown was also delayed in the LPE-treated fruits. LPE treatment slowed the development of brown spots on the peel tissue. Both peel and pulp tissue of LPE-treated fruits had lower ion leakage compared with the control. Fruit peel slices treated with LPE for 3 hours also showed a decrease in ion leakage and respiration rate at 24 hours after treatment. Results of the present study indicate that a postharvest dip treatment with LPE may improve shelf life of banana fruit by 1-2 days. These results suggest that LPE may improve shelf life by maintaining membrane integrity, reducing respiration, and slowing the breakdown of starch and cell walls during ripening and senescence of banana fruit tissue.
\end{abstract}

Banana fruit (Musa sp.); 'Cavendish' variety is one of the most important grown and widely consumed fruit in the world. It is also the most frequently purchased fruit in western countries (Americafruit, 2001). Commercially, bananas are harvested mature green, and shipped refrigerated to the

Received for publication 10 Sept. 2014. Accepted for publication 8 Jan. 2015.

This study was conducted at the University of Wisconsin and supported, in part, by South Valley University which provided a scholarship to Zienab Ahmed to pursue her $\mathrm{PhD}$ studies and by the College of Agricultural and Life Sciences, University of Wisconsin. This study is portion of a thesis submitted by Zienab Ahmed in partial fulfillment of $\mathrm{PhD}$ degree requirements.

${ }^{1}$ To whom reprint requests should be addressed. e-mailjppalta@wisc.edu. importing countries. Upon arrival to their destination, the green bananas are stored in modified atmospheric rooms at the distribution centers where they are treated with ethylene gas before marketing (Ahmed et al., 2006). This gas treatment is known to provide uniformly ripened fruit within few days (Reid, 1992). Fruit peel color and firmness are commonly used indexes of banana marketability (Kader, 1992).

The peel color of banana fruit is the primary criterion for fruit ripening (Kader, 1992; Medlicott et al., 1992; Seymour et al., 1993). Seven distinct visual color stages have been distinguished as banana fruit ripens where the peel color changes from dark green (stage 1) to yellow (stage 5) followed by the appearance of dark brown spots (stage 7) when about $20 \%$ of the fruit surface is covered with brown spots and fruit is considered unmarketable (Tapre and Jain, 2012). These seven color stages are presented in a color chart that is now used for quality evaluation by the industry. Fruits are considered marketable as long as the peel color is mostly yellow with very little brown spots up to stage 6 . Ripened banana fruit goes from marketable to unmarketable within 1-3 d. Thus, increasing the shelf life of the banana fruit by just a couple days would add significant commercial value.

Banana is classified as a climacteric fruit (Rhodes, 1970). In this fruit, series of physiological and biochemical changes are known to lead to the development of soft edible fruits (Prasanna et al., 2007; Tapre and Jain, 2012). Some of the primary changes during this ripening process include an increase in membrane permeability (ion leakage), loss of fruit pulp firmness, decrease in starch, increase in sugar, decrease of peel thickness as well as changes in color and aroma (Baur and Workman, 1964; Goldstein and Wick, 1969; Ludford, 1987; Seymour et al., 1993; Wade and Bishop, 1978).

Generally, fruits such as bananas are delicate and have a short shelf life after ripening (Kader 1992). Historically, many postharvest treatments have been investigated to increase the shelf life of banana fruit, however, only with limited success (Kader, 1992). In several studies, a postharvest treatment with 1-methycyclopropene (1-MCP) has been tried to improve shelf life of banana fruit (Golding et al., 1998; Harris et al., 2000). In many fruit, gas treatment with $1-\mathrm{MCP}$ has been found to block ethylene receptors and prevent ethylene effects on fruit tissues and delay ripening (Serek et al., 1994, 1996; Sisler and Serek, 1997). Although treatment with 1-MCP maintained fruit firmness, it also inhibited peel color changes and aroma and flavor development (Botrel et al., 2002; Jiang et al., 1999; Jiang et al., 2002; Lohani et al., 2004; Pelayo et al., 2003). Because of these undesirable effects, 1 -MCP treatment is not considered commercially suitable for extending the shelf life of banana fruit (Golding et al., 1998; Pelayo et al., 2003; Watkins, 2006). More recently effect of preharvest and postharvest application of calcium has been investigated. However these treatments did not have any significant effect on the shelf life (greenlife) of banana fruit.

Previous studies conducted in our laboratory have shown that both pre- and postharvest application of LPE is able to reduce senescence and promote shelf life of fruits, cut flowers, and leaf tissue (Farag and Palta, 1991a, 1991b; Farag and Palta, 1993a; Kaur and Palta, 1997; Ozgen et al., 2005; Ryu et al., 1997; Snider et al., 2003). Several studies have verified and provided additional evidence in support of the positive effect of LPE on the shelf life of red pepper, tomato, and grape fruits (Hong, 2006; Hong and Chung, 2006; Hong et al., 2007). There is additional evidence that phospholipids and lysophospholipids such as LPE are signaling molecules that can regulate plant growth and 
development (Chapman, 1998; Cowan, 2006a, 2006b; Laxalt and Munnik, 2002; Meijer and Munnik, 2003). The exact mechanism by which LPE can delay senescence and improve shelf life is not known. However, LPE has been found to inhibit the activity of phospholipase D (PLD), in highly specific manner (Ryu et al., 1997). PLD is known to be activated during ethyleneinduced senescence (Bao et al., 2007; Fan et al., 1997; Ryu and Wang, 1995; Wang, 2001, 2002) and this activation leads to membrane breakdown. Thus it appears that LPE may be enhancing shelf life by preserving membrane health during senescence of fruit.

At present there is no commercially viable product available to improve shelf life of banana fruit. The present study was conducted to determine the potential use of a postharvest dip treatment of LPE to improve shelf life of banana fruit.

\section{Materials and Methods}

\section{Plant materials}

Dessert Bananas Cavendish cultivar (Chiquita ${ }^{\circledR}$ no. 4011 ) at ripeness stage about 2.5 (peel about $75 \%$ green) were purchased from a local supermarket in Madison, WI. The fruit hands were washed with bleach $(0.5 \%)$ for $2 \mathrm{~min}$ and rinsed three times with distilled water then pat dried. The fruits were sorted for uniformity of weight and shape. To minimize variability, equal numbers of uniform fruits were separated from each hand and divided among the LPE and control (water) treatments.

\section{Whole intact fruit experiments}

LPE solution preparation and dip treatment of fruits. LPE derived from soy lecithin was obtained from Doosan Serdary Research Laboratories. Englewood, NJ. To prepare dip solution, LPE was suspended in distilled water by sonication as described by Ozgen et al. (2005) using (Sonic dismembrator Model 550; Fisher Scientific, Pittsburgh, PA). Fruits were dipped in solution of various concentration of LPE for $30 \mathrm{~min}$ and the control fruits were dipped in distilled water. Fruits were stored at room temperature and various measurements and observations were made at different time periods.

Visual observations on fruit marketability. Fruits were dipped in various concentration of LPE $(0,200$, and $500 \mathrm{ppm})$ for $30 \mathrm{~min}$ and observed for color changes for $7 \mathrm{~d}$. Three replicate per each treatment were used and each replication contained 20 fruits. When about $20 \%$ of the fruit surface was covered with brown spots, the fruit was considered unmarketable.

Fruit weight loss, fruit thickness loss, fruit firmness, and ion leakage. Fifty fruits were dipped in LPE (500 ppm) or distilled water. Each fruit was weighed at the start of the experiment and again at the end of experiment ( $5 \mathrm{~d}$ after treatment). Weight loss was determined as percent of the initial weight. For each fruit, thickness was measured at the midpoint (lengthwise) using digital caliper at the start of the experiment and again at the same place $5 \mathrm{~d}$ after treatment. A reduction in the fruit thickness was calculated as \% changes in the fruit thickness as compared with the initial reading. Fruit pulp firmness was determined for 50 fruits using Penetrometer (Model FT-011, QA Supplies Norfolk, VA) equipped with a probe (tip diameter $10 \mathrm{~mm}$ ). This instrument gives force of resistance $\left(\mathrm{kg} \cdot \mathrm{mm}^{-1}\right)$. The data were expressed as force needed for penetration in newtons $(\mathrm{N})$ by multiplying the reading by 9.8066 (Dadzie and Orchard, 1997). For this purpose, the pressure required for the probe to penetrate to $7 \mathrm{~mm}$ depth into the fruit pulp was measured. Three readings were taken from each fruit at three separate locations (right, middle, and left).

Ion leakage from the peel tissue was measured using a standard procedure (Fan and Sokorai, 2005) with a slight modification. Briefly, the fruits were transversely sliced at the midpoint ( $1 \mathrm{~cm}$ thick) and the peel was separated. The peel was then cut into 2-mm slices and put into tubes containing $20 \mathrm{~mL}$ of distilled water. Initial electrolyte leakage was measured $(\mathrm{C} 1)$ by a conductivity meter (YSI Model 32, Yellow Springs Instrument, Inc., Yellow Springs, $\mathrm{OH}$ after shaking the tubes on a gyratory shaker at $250 \mathrm{rpm}$ at room temperature (23 \pm $2{ }^{\circ} \mathrm{C}$ ) for $15 \mathrm{~min}$. The samples were then autoclaved at $121^{\circ} \mathrm{C}$ for $15 \mathrm{~min}$ and conductivity was measured again $(\mathrm{Ct})$. The percent of ion leakage (IL \%) was calculated for all values using this equation:

$$
\mathrm{IL}(\%)=\frac{\mathrm{C} 1}{\mathrm{Ct}} 100
$$

Total soluble solids, ion leakage from peel and pulp tissue, starch iodine test, and respiration rate. In a separate experiment, 50 fruits were dipped in LPE 500 ppm solution and distilled water as a control treatment. Three fruits were sampled from each treatment everyday for $7 \mathrm{~d}$ to determine total soluble solids (TSS) and ion leakage. TSS were measured by blending $30 \mathrm{~g}$ of fruit pulp tissue (from the middle portion of the fruit) with $90 \mathrm{~mL}$ distilled water. The water was extracted by filtering the slurry. TSS were estimated by placing 1-2 drops of the filtrate on the prism of a digital refractometer (Model PR-32 $\alpha$, Atago Co. Ltd, Japan). The recorded value was multiplied by three to correct for sample dilution (Dadzie and Orchard, 1997). Ion leakage was measured using the procedure described above.

Starch degradation (conversion of starch into sugar) in the fruits was visually evaluated by staining sections of fruit with iodinepotassium iodide (Blankenship et al., 1993; Dadzie and Orchard, 1997). For this purpose, $2-\mathrm{cm}$ thick transverse slices were removed and stained on one side of the cut for $5 \mathrm{~s}$ in iodine solution (containing $10 \mathrm{~g}$ potassium iodide and $2.5 \mathrm{~g}$ iodine per liter). From each treatment (LPE 500 ppm, distilled water) 16 fruits were randomly sampled at $5 \mathrm{~d}$ after treatment. Stained cut surfaces with dark blue color indicated high starch (not breakdown into free sugars) (Blankenship et al., 1993; Dadzie and Orchard, 1997).

For measuring respiration rate, three fruits were placed in a 2 -L airtight container for one hour. A $10 \mathrm{~mL}$ gas sample was withdrawn from the headspace of the container to quantify $\mathrm{CO}_{2}$ concentration. An infrared gas analyzer equipped with an automatic sampler (LI-COR LI-820, Lincoln, NE) was used to determine $\mathrm{CO}_{2}$ concentration. Three independent air samples were taken per chamber daily and respiration rate were expressed as $\mathrm{mL} \mathrm{CO}_{2} / \mathrm{kg} / \mathrm{h}$ on fresh weight basis. Air samples of known concentration (3 ppm $\mathrm{CO}_{2}$ ) were routinely used as an internal standard. For calculation purposes, the free headspace of each chamber was estimated by subtracting the fruit volume from the total volume of each chamber. Each experiment was repeated at least three times.

\section{Experiments with fruit peel slices}

Fruit (at 2.5 ripening stage) peel slices ( $5 \mathrm{~mm}$ thick) were dipped in 100 ppm LPE for $3 \mathrm{~h}$ to investigate the influence of LPE on respiration rate and ion leakage. The slices used for each treatment were separated from same fruit and divided between two treatments (LPE and control) to reduce the variability among fruits. One day after treatment, ion leakage and respiration rates were measured using the same procedure as for whole fruits with slight modification. For the ion leakage about $10 \mathrm{~g}$ of peel slices were used for each replication and three replications were used for each treatment. For respiration rate the peel slices (about $10 \mathrm{~g}$ ) were placed in a $50-\mathrm{mL}$ air tight glass container for $1 \mathrm{~h}$ and a $1-\mathrm{mL}$ gas sample was withdrawn from the head space.

\section{Statistical analysis}

Data were analyzed by one-way analysis of variance in PROC GLM procedure of Statistical Analysis System [SAS version 9.2 for Windows, SAS Institute Inc., Cary, NC (SAS ${ }^{\circledR}$, 2009)]. Mean comparisons were performed using Duncan's multiple range test to determine the significance differences at $P \leq 0.05$.

\section{Results}

Whole intact fruit experiments. Banana fruits at stage 2.5 (about $75 \%$ green) were dipped in various concentrations of LPE $(0,200$, and $500 \mathrm{ppm})$ and observed for color changes for $7 \mathrm{~d}$. At 5 and $6 \mathrm{~d}$ after dip treatment, significantly higher numbers of fruits remained marketable for $500 \mathrm{ppm}$ LPE treatment as compared with $200 \mathrm{ppm}$ treatment or control. For example, at day 6 after dip treatment only $21.4 \%$ fruits remained marketable for control and $47.6 \%$ for $200 \mathrm{ppm}$ LPE, whereas $64.1 \%$ fruits dipped in 500 ppm LPE remained marketable at the same time (Table 1). Repeated experiments showed that the concentration of 500 ppm LPE gave consistent results. So that for all subsequent studies the concentration of LPE 500 ppm was used. 
Table 1. Effect of dip treatment in lysophosphatidylethanolamine (LPE) on banana fruit marketability.

\begin{tabular}{lcccc}
\hline \multicolumn{5}{c}{ Marketable fruit (\% of total) } \\
\hline & \multicolumn{4}{c}{ Day after dip treatment } \\
\cline { 2 - 5 } Treatment & 4 & 5 & 6 & 7 \\
Control & $83.1+0.75 \mathrm{~b}^{\mathrm{y}}$ & $46.8+0.30 \mathrm{c}$ & $21.4+1.89 \mathrm{c}$ & $19.5+1.80 \mathrm{~b}$ \\
LPE 200 ppm & $93.6+0.37 \mathrm{a}$ & $56.1+1.28 \mathrm{~b}$ & $47.6+2.07 \mathrm{~b}$ & $39.6+1.61 \mathrm{a}$ \\
LPE 500 ppm & $96.0+2.02 \mathrm{a}$ & $72.9+2.26 \mathrm{~b}$ & $64.1+0.68 \mathrm{a}$ & $43.7+1.58 \mathrm{a}$ \\
\hline
\end{tabular}

${ }^{2}$ Banana fruits were dipped in 200,500 ppm LPE or water (control) for $30 \mathrm{~min}$ and stored at room temperature for $7 \mathrm{~d}$. Data for marketability were recorded from 20 fruits/replication and three replications/ treatment $(n=3)$ starting at day 4.

${ }^{y}$ Mean values within a column that have different letter are significantly different at $P \leq 0.05$ as determined by Duncan's multiple range test $(n=3)$.
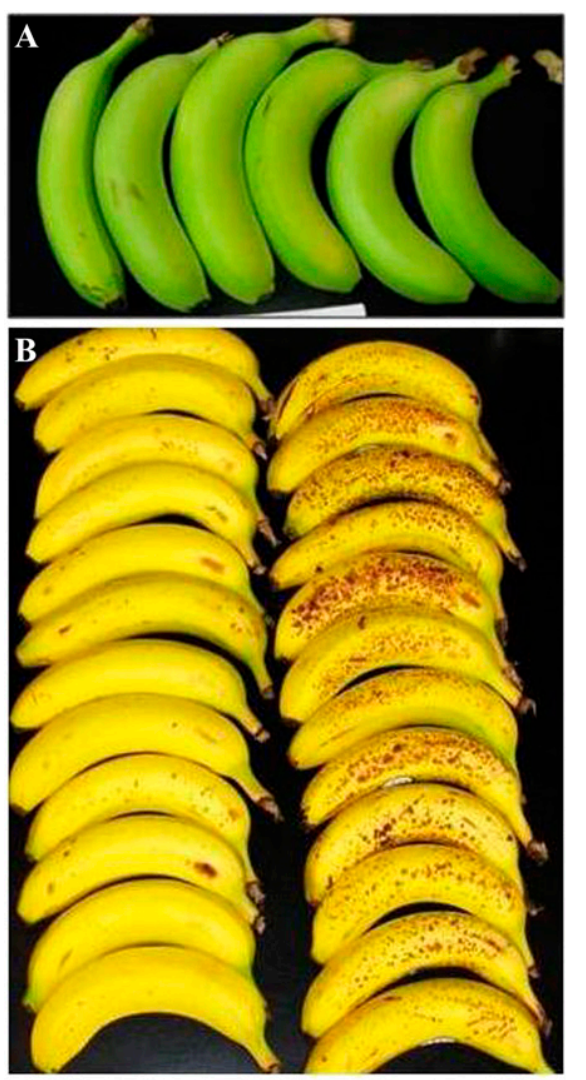

LPE

Control

Fig. 1. Visual observation of banana fruits (A) at the first day before treatment and $(\mathbf{B})$ at day 5 after treatment. The fruits were dipped in solution of $500 \mathrm{ppm}$ lysophosphatidylethanolamine (LPE) or distilled water (control) for $30 \mathrm{~min}$ then stored at room temperature for $5 \mathrm{~d}$.

Using the banana ripeness chart, loses in fruit marketability occur when the peel begins to develop brown spots as in stage 7 . We found that the fruit treated with LPE were two ripening stages behind control at day 5 after treatment. The LPE-treated fruits at day 5 were fully yellow and some fruits were still with green tips (stage 5) while control fruit had many of brown spots that became bigger and overlapped in some area of the peel surface (Fig. 1). Moreover, the control fruits had very damaged tips with black color, the black color started to grow along the fruit angles as fruit ripened. The iodine test on fruits pulp slices showed more dark blue color on the surface of LPE-treated fruit as indication of the presence of starch while the control fruits showed less blue or no color on the stained surface (Fig. 2).

LPE treatment had no significant effect on fruit weight loss during ripening while it had a significantly positive effect on fruit firmness and fruit thickness at day 5 after treatment (Table 2). LPE-treated fruits had almost the same percent of fruit weight loss $(6.40 \%)$ as the control $(6.47 \%)$ after $5 \mathrm{~d}$ from the treatment. Loss of fruit thickness was about $1 \%$ less in the LPE-treated fruits as compared with the control and this difference was significant (Table 2). LPE-treated fruit firmness was about $12 \%$ higher as compared with control fruits. The average firmness of LPEtreated fruits was $9.3 \mathrm{~N}$ as compared with 8.2 $\mathrm{N}$ for control fruits (Table 2).

The electrolyte leakage from the peel tissue was significantly 3\% higher in the control fruit peel tissues samples as compared with the LPE-treated fruits. On average the ion leakage of the LPE-treated fruits was $35.9 \%$ compared with $38.78 \%$ for the control (Table 2).

In a separate experiment, LPE treated and control fruits were evaluated for TSS for seven days following dip treatment (Table 3 ). During this period ion leakage from the peel and pulp tissue was also measured daily. In general, the ion leakage was consistently peel tissue on any given day for both the LPEtreated and control fruits (Table 3). The ion leakage from the peel tissue of LPE-treated fruit was significantly lower than the control fruits for each day. In addition, the ion leakage from the pulp tissue of LPE-treated fruits was significantly lower as compared with control fruits except day 7 (Table 3 ).

Total soluble solids nearly doubled over the $7 \mathrm{~d}$ of observation (Table 3 ) irrespective of treatment. LPE-treated fruits had lower TSS as compared with control fruits. However, these differences were not significant for fruits evaluated at day 4 and 5 after LPE dip treatment (Table 3).

Respiration rates of same fruits were measured for $7 \mathrm{~d}$ after LPE dip treatment. The respiration rate increased during the first $3 \mathrm{~d}$ after treatment then declined in both treatments (data not shown). However, no significant differences among the two treatments were found from day to day during this ripening period. There was high variability in respiration rates among various fruits within the same treatment. higher from the pulp tissue as compared with
Fruit slices experiment. To reduce variability among fruits, dip treatments were employed to fruit slices removed from the same fruit. For this purpose, fruit peel slices 5 $\mathrm{mm}$ thick were dipped in either $100 \mathrm{ppm}$ LPE or distilled water as control for $3 \mathrm{~h}$. The respiration rate and ion leakage from these peel slices was recorded $24 \mathrm{~h}$ after treatment. Significant reduction in ion leakage and respiration rate was found by LPE treatment (Fig. 3). The LPE-treated tissues had significantly lower respiration rate $\left(19.6 \mathrm{~mL} \mathrm{CO}_{2} /\right.$ $\mathrm{kg} / \mathrm{h})$ compared with the control $(23.8 \mathrm{~mL}$ $\mathrm{CO}_{2} / \mathrm{kg} / \mathrm{h}$ ) and ion leakage was reduced from $24 \%$ in control to $18 \%$ in LPE-treated peel slices (Fig. 3).

\section{Discussion}

Our results show that a dip treatment of banana fruit in a $500 \mathrm{ppm}$ LPE solution extended the shelf life. At $6 \mathrm{~d}$ after treatment, LPE treatment resulted in nearly three times more marketable fruit $(64.1 \%)$ as compared with the control (21.4\%) (Table 1). The LPE treatment appears to add about $2 \mathrm{~d}$ of shelf life. For example, $7 \mathrm{~d}$ after treatment $43.7 \%$ of LPE-treated fruits were marketable and this was similar to $46.8 \%$ marketable fruit in the control at day 5 after treatment (Table 1). These results are consistent with previous studies where LPE was found to improve shelf life of tomato, cranberry, red pepper, and grape fruits (Farag and Palta, 1993b; Hong, 2006; Hong and Chung, 2006; Hong et al., 2007; Ozgen et al., 2005). Once ripening is initiated, banana fruits have a relatively short shelf life. Therefore, improving shelf life by couple more days can add significant commercial value. The results of the present study show that LPE may have potential commercial value for improving shelf life of banana fruits by about 1-2 d.

It is important to point out that although LPE treatment improved shelf life, this treatment does not appear to have an undesired effect on fruit marketability and visual quality. Many studies have investigated the potential of a postharvest treatment with 1-MCP to improve the shelf life of banana fruits (Botrel et al., 2002; Jiang et al., 1999; Jiang et al., 2002; Pelayo et al., 2003; Zhang et al., 2006). 1-MCP treatment of banana fruits after ethylene treatment has shown to maintain fruit firmness, but delayed color changes as well as aroma development. Thus, 1-MCP treatment negatively affected the marketability of the banana fruits (Golding et al., 1998; Golding et al., 1999; Pelayo et al., 2003; Watkins, 2006).

Changes in cell membrane properties leading to enhanced ion leakage has been long recognized as a cellular event during ripening of climacteric fruits such as banana (Baur and Workman, 1964; Bugaud et al., 2013; Fernandes et al., 1979). Our results show that a dip treatment of whole banana fruit in LPE decreased ion leakage from both peel and pulp tissues (Tables 2 and 3 ). A significant decrease in this leakage was consistently observed from days 1-7 (Table 3 ). 


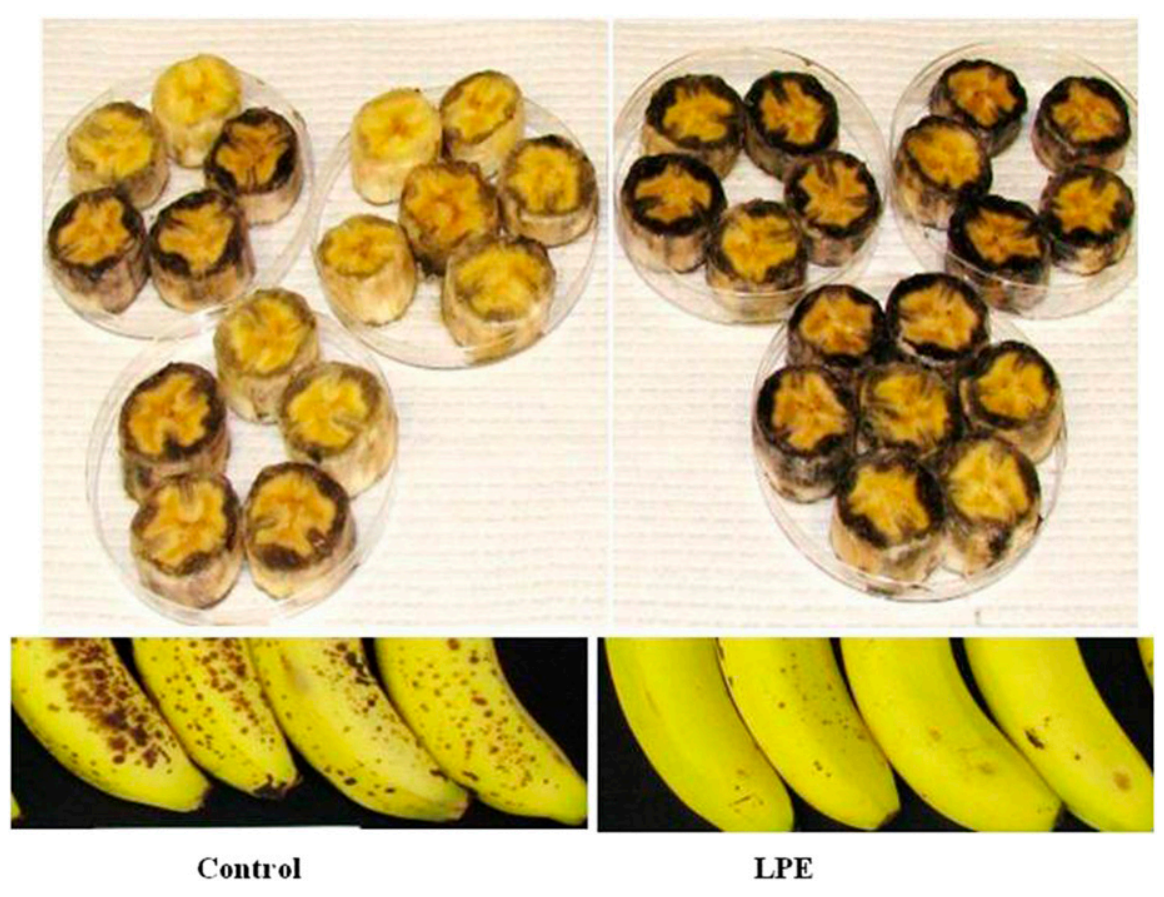

Fig. 2. Iodine test for detecting starch in fruit pulp slices at day 5 after treatment. Fruits were dipped in solution of $500 \mathrm{ppm}$ lysophosphatidylethanolamine (LPE) or water (control) for 30 min then stored at room temperature for $5 \mathrm{~d}$. For the iodine test, a slice from the middle of each fruit was cut and dipped in iodine solution for one minute. For this experiment 15 fruits from control and LPE-treated fruits were cut, stained and observed. Pictures here show representative samples from each treatment.

Table 2. Effect of lysophosphatidylethanolamine (LPE) on loss of fruit thickness and ion leakage from peel tissue. $^{z}$

\begin{tabular}{lcccc}
\hline Treatment & $\begin{array}{c}\text { Loss in fruit } \\
\text { thickness (\%) }\end{array}$ & Loss in fruit wt (\%) & $\begin{array}{c}\text { Firmness of } \\
\text { pulp tissue (N) }\end{array}$ & $\begin{array}{c}\text { Electrolyte leakage } \\
\text { from peel tissue (\%) }\end{array}$ \\
\hline Control & $2.9 \pm 0.2 \mathrm{a}^{\mathrm{y}}$ & $6.5 \pm 0.1 \mathrm{a}$ & $8.2 \pm 0.01 \mathrm{~b}$ & $38.8 \pm 1.3 \mathrm{a}$ \\
LPE & $2.3 \pm 0.1 \mathrm{~b}$ & $6.4 \pm 0.1 \mathrm{a}$ & $9.3 \pm 0.01 \mathrm{a}$ & $35.9 \pm 0.9 \mathrm{~b}$ \\
\hline
\end{tabular}

zThe fruits were dipped in solution of $500 \mathrm{ppm}$ LPE for $30 \mathrm{~min}$ then kept at the room temperature for $5 \mathrm{~d}$.

${ }^{\mathrm{y}}$ Mean values within a column that have different letter are significantly different at $P \leq 0.05(n=3)$.

Table 3. Effect of lysophosphatidylethanolamine (LPE) on total soluble solids (TSS) of the fruit pulp and on the ion leakage from the pulp and peel tissues of banana fruit. ${ }^{\mathrm{z}}$

\begin{tabular}{|c|c|c|c|c|c|c|}
\hline \multirow{2}{*}{$\begin{array}{l}\text { Days after } \\
\text { treatment }\end{array}$} & \multicolumn{2}{|c|}{ TSS (\%) } & \multicolumn{2}{|c|}{ Peel ion leakage (\%) } & \multicolumn{2}{|c|}{ Pulp ion leakage (\%) } \\
\hline & Control & LPE & Control & LPE & Control & LPE \\
\hline 1 & $9.7 \pm 0.3 \mathrm{a}^{\mathrm{y}}$ & $7.9 \pm 0.5 b$ & $14.5 \pm 1.3 \mathrm{a}$ & $9.5 \pm 0.4 \mathrm{~b}$ & $28.0 \pm 2.9 \mathrm{a}$ & $27.8 \pm 1.8 \mathrm{a}$ \\
\hline 2 & $14.3 \pm 0.2 \mathrm{a}$ & $13.3 \pm 0.3 \mathrm{~b}$ & $25.4 \pm 1.0 \mathrm{a}$ & $20.2 \pm 0.5 \mathrm{~b}$ & $34.3 \pm 3.9 \mathrm{a}$ & $28.5 \pm 2.5 b$ \\
\hline 3 & $15.4 \pm 0.4 \mathrm{a}$ & $14.4 \pm 0.2 \mathrm{~b}$ & $25.2 \pm 1.5 \mathrm{a}$ & $21.9 \pm 0.6 \mathrm{~b}$ & $38.8 \pm 1.1 \mathrm{a}$ & $31.5 \pm 2.3 b$ \\
\hline 4 & $15.1 \pm 0.1 \mathrm{a}$ & $14.5 \pm 0.3 \mathrm{a}$ & $27.8 \pm 0.6 \mathrm{a}$ & $23.5 \pm 0.5 \mathrm{~b}$ & $40.4 \pm 2.1 \mathrm{a}$ & $32.0 \pm 2.2 \mathrm{~b}$ \\
\hline 5 & $15.8 \pm 0.2 \mathrm{a}$ & $15.3 \pm 0.2 \mathrm{a}$ & $30.6 \pm 1.7 \mathrm{a}$ & $27.4 \pm 1.1 \mathrm{~b}$ & $41.6 \pm 1.0 \mathrm{a}$ & $32.1 \pm 0.8 b$ \\
\hline 6 & $16.4 \pm 0.3 \mathrm{a}$ & $15.5 \pm 0.3 \mathrm{~b}$ & $35.7 \pm 0.8 \mathrm{a}$ & $29.9 \pm 0.8 \mathrm{~b}$ & $42.8 \pm 1.2 \mathrm{a}$ & $33.2 \pm 1.4 \mathrm{~b}$ \\
\hline 7 & $17.9 \pm 0.5 \mathrm{a}$ & $16.1 \pm 0.4 \mathrm{~b}$ & $37.3 \pm 2.2 \mathrm{a}$ & $34.3 \pm 1.9 \mathrm{a}$ & $43.0 \pm 1.7 \mathrm{a}$ & $35.6 \pm 1.0 \mathrm{~b}$ \\
\hline
\end{tabular}

${ }^{\mathrm{z}}$ Fruits were dipped in LPE $500 \mathrm{ppm}$ for $30 \mathrm{~min}$ and stored at room temperature for a period of $7 \mathrm{~d}$.

${ }^{y}$ Mean comparisons were made between paired control and LPE treatment for each index every day. Mean values of LPE and control that have the same letter are not significantly different $P \leq 0.05(n=6)$.

Similarly peel slices dipped in LPE showed a decrease in ion leakage, as compared with control at $24 \mathrm{~h}$ after treatment (Fig. 3). These results with whole fruit and peel slices are consistent with previous studies where LPE was shown to retard senescence and reduce ion leakage from fruit, leaf, and flower tissue (Farag and Palta, 1993b; Kaur and Palta, 1997; Ryu and Wang, 1995). The exact mechanism by which LPE can decrease ion leakage during senescence and aging is not known. An increase in the activity of PLD has been proposed as a mechanism by which some of the cellular changes are triggered by ethylene during senescence (Bao et al., 2007; Fan et al., 1997; Ryu and Wang, 1995; Wang 2001, 2002). Since PLD cleaves the head group of membrane phospholipids, an increase in its activity could destabilize cell membranes and result in enhanced ion leakage from the cell (Li et al., 2009). Interestingly exogenously applied LPE has been shown to inhibit the activity of PLD in vitro (Ryu et al., 1997). Therefore, LPE may be preserving membrane integrity during senescence, in part, by inhibiting PLD. The results of our study on reduction of ion leakage from the peel and pulp tissues are consistent with this suggestion.

Fruit respiration rate and ethylene production are the main physiological factors that change and define the climacteric group of fruits such as banana (Seymour et al., 1993). Increase in the respiration rate is known to contribute to postharvest losses and enhance aging and senescence of perishable commodities (Kader, 1986; Kay, 1991). Therefore, a reduction in respiration rate will reduce the utilization of substrates such as free sugars and could extend the postharvest life (Kader, 1986; Saltveit, 2004). Our results show that LPE was able to reduce respiration rate in banana fruit (Fig. 3) as well as breakdown of starch into sugar (Fig. 2). Therefore, fruit shelf life was extended and senescence was delayed after LPE treatment. This is supported by previous studies when LPE treatment was found to reduce respiration rate and ethylene production of tomato fruit resulting in retarding senescence of fruits and leaves (Farag and Palta, 1991a, 1991b; Farag and Palta, 1993a). Our results show that LPE-treated fruits had higher firmness of the pulp tissue at $5 \mathrm{~d}$ after treatment (Table 2). Fruit softening is known to result from alteration in structure and composition of cell wall, partial or complete breakdown of cell wall polysaccharides; such as pectin and cellulose, as well as hydrolysis of starch and other storage polysaccharides (Fuchs et al., 1980; Selvaraj and Kumar, 1989; Selvaraj et al., 1989; Tucker, 1993; Tucker and Grierson, 1987). Consistent with this, we found higher starch and lower sugar contents in the pulp of LPE-treated fruits (Table 3; Fig. 2). Therefore, higher fruit firmness in LPE-treated fruits could be, in part, due to slower breakdown of starch into sugar. Cell wall degrading enzymes such as polyglacturonases $\left(\mathrm{PG}_{\mathrm{S}}\right)$, pectin methyl esterases, pectate lyases, and rhamnogalacturonases are known to be involved in fruit tissue softening (Prasanna et al., 2007). Previous work on tomato fruit showed an in vitro inhibition of the activity of PG by LPE (Farag and Palta, 1992). Although several cell wall hydrolytic enzymes are known to be involved in the softening of banana fruit pulp, polyglactronase is known to be the major softening enzymes in this fruit (Ali et al., 2004). An inhibition of the activity of polyglactronase by LPE was reported in tomato fruit tissue (Farag and Palta, 1992). These published reports, taken together with the results of the present study (Table 3; Fig. 2), suggest that LPE may be maintaining fruit firmness by reducing cell wall breakdown during ripening or by regulating the activities of some of these hydrolytic enzymes. This action of LPE treatment in reducing softening and that of reducing starch breakdown have been also reported for the treatment of fruits with auxin (Lohani et al., 2004). Exogenous application of indol-3-acetic acid has been shown to delay starch degradation and sugar formation in banana (Purgatto et al., 2001) and delay the activity of cell wall hydrolytic 

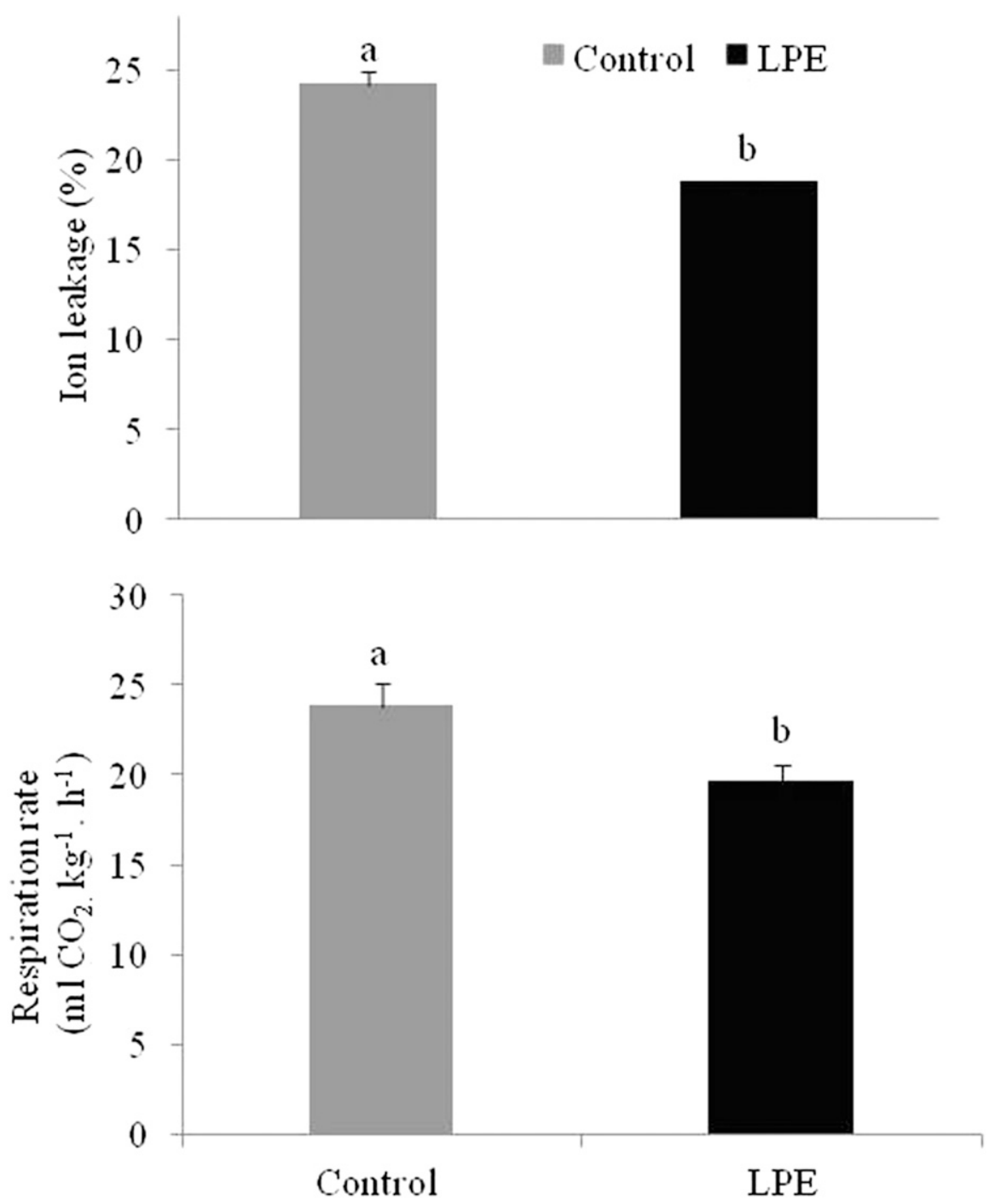

Fig. 3. Influence of lysophosphatidylethanolamine (LPE) dip treatment on ion leakage and respiration rate of banana peel slices. Peel slices of fruit ( 2.5 stage) $5 \mathrm{~mm}$ thick were dipped in $100 \mathrm{ppm}$ LPE or distilled water (control) for $3 \mathrm{~h}$. Peel slices from the same fruit were divided among the two treatments to reduce the variability. Measurements were recorded $24 \mathrm{~h}$ after treatment. Each value is the mean of three replications $(n=3)$. Mean values that have the same letter are not significantly different $P \leq 0.05$.

enzymes (Lohani et al., 2004). Therefore, LPE action also appears to be, in part, similar to auxin.

In conclusion, banana is a perishable fruit with very short shelf life. So far no postharvest treatment is available to extend the shelf life of this fruit without undesirable effect on ripening and fruit marketability. Our results suggest that LPE has a potential to extend the shelf life of banana fruit by about 1-2 d without negative impact on fruit marketability.

\section{Literature Cited}

Ahmed, S., A.Z. Chatha, A. Nasir, A. Abdel Aziz, and M. Mohsen. 2006. Effect of relative humidity on the ripening behaviour and quality of ethylene treated banana fruit. J. Agr. Soc. Sci. 2:54-56.

Ali, Z.M., L.H. Chin, and H. Lazan. 2004. A comparative study on wall degrading enzymes, pectin modifications and softening during ripening of selected tropical fruits. Plant Sci. 167:317-327.
Chapman, K.D. 1998. Phospholipase activity during plant growth and development and in response to environmental stress. Trends Plant Sci. 3:419-426.

Cowan, A.K. 2006a. Lyso-phosphatidylethanolamine (LPE) as a plant bioregulator. Acta Hort. 727:527-536.

Cowan, A.K. 2006b. Phospholipids as plant growth regulators. Plant Growth Regulat. 48:97-109.

Dadzie, B.K. and J.E. Orchard. 1997. Routine postharvest screening of banana/plantain hybrids: Criteria and methods. INIBAP Tech. Guideline. 35:9-15.

Fan, L., S. Zheng, and X. Wang. 1997. Antisense suppression of phospholipase D alpha retards abscisic acid- and ethylene-promoted senescence of postharvest Arabidopsis leaves. Plant Cell Online 9:2183-2196.

Fan, X. and K.J.B. Sokorai. 2005. Assessment of radiation sensitivity of fresh-cut vegetables using electrolyte leakage measurement. Postharvest Biol. Technol. 36:191-197.

Farag, K.M. and J.P. Palta. 1991a. Enhancing ripening and keeping quality of apple and cranberry fruits using lysophosphatidylethanolamine, a natural lipid. HortScience 26:683 (abstr).

Farag, K.M. and J.P. Palta. 1991b. Use of lysophosphatidylethanolamine, a natural lipid, to delay tomato fruit and leaf senescence. HortScience 26:683 (abstr.).

Farag, K.M. and J.P. Palta. 1992. Evidence for a specific inhibtion of the activity of polyglactronase by lysophosphatidyethanolamine in tomato fruit tissue: Impilcations enhancing storage stability and reducing absicisson of the fruit. Plant Physiol. 99:54 (abstr)

Farag, K.M. and J.P. Palta. 1993a. Use of lysophosphatidylethanolamine, a natural lipid, to retard tomato leaf and fruit senescence. Physiol. Plant. 87:515-521

Farag, K.M. and J.P. Palta. 1993b. Use of natura lipids to accelerate ripening and enhance storage life of tomato fruit with and without ethephon. HortTechnology 3:62-65.

Fernandes, K.M., V.D. De Carvalho, and J. CalVidal. 1979. Physical changes during ripening of silver bananas. J. Food Sci. 44:1254-1255.

Fuchs, Y., E. Pesis, and G. Zauberman. 1980 Changes in amylase activity, starch and sugar contents in mango fruit pulp. HortScience 13:155-160.

Golding, J.B., D. Shearer, W.B. McGlasson, and S.G. Wyllie. 1999. Relationships between respiration, ethylene, and aroma production in ripening banana. J. Agr. Food Chem. 47:1646-1651.

Golding, J.B., D. Shearer, S.G. Wyllie, and W.B. McGlasson. 1998. Application of 1-MCP and propylene to identify ethylene-dependent ripening processes in mature banana fruit. Postharvest Biol. Technol. 14:87-98.

Goldstein, J.L. and E.L. Wick. 1969. Lipid in ripening banana fruit. J. Food Sci. 34:482-484.

Harris, D.R., J.A. Seberry, R.B.H. Wills, and L.J. Spohr. 2000. Effect of fruit maturity on efficiency of 1-methylcyclopropene to delay the ripening of bananas. Postharvest Biol. Technol. 20:303-308.

Hong, J.H. 2006. Lysophosphatidylethanolamine enhances ripening and prolongs shelf life in tomato fruit: Contrasting effect on mature green vs red tomatoes. Hort. Environ. Biotechnol. 47:55-58.

Hong, J.H. and G. Chung. 2006. Effects of application of lysophosphatidylethanolamine on marketable yield and storability of red pepper (Capsicum annuum L.). Hort. Environ. Biotechnol. 47:243-246. 
Hong, J.H., S.K. Hwanga, G. Chunga, and A.K. Cowan. 2007. Influence of lysophosphatidyethanolamine application on fruit quality of thampson seedless grapes. J Appl Hort 9:112-114.

Jiang, Y., D.C. Joyce, and A.J. Macnish. 1999. Responses of banana fruit to treatment with 1methylcyclopropene. Plant Growth Regulat. 28:77-82.

Jiang, Y., D.C. Joyce, and A.J. Macnish. 2002. Softening response of banana fruit treated with 1-methylcyclopropene to high temperature exposure. Plant Growth Regulat. 36:7-11.

Kader, A.A. 1986. Biochemical and physiological basis for effects of controlled atmospheres. Food Technol. Biotechnol. 40:99-104.

Kader, A.A. 1992. Post harvest technology of horticultural crops. 2nd ed. University of California.

Kaur, N. and J.P. Palta. 1997. Postharvest dip in a natural lipid, lysophosphatidylethanolamine, may prolong vase life of snapdragon flowers. HortScience 32:888-890.

Kay, S.J. 1991. Postharvest technology of perishable crops. Van Nostrand Reinhold, New York, NY.

Laxalt, A.M. and T. Munnik. 2002. Phospholipid signaling in plant defence. Curr. Opin. Plant Biol. 5:1-7.

Li, M., Y. Hong, and X. Wang. 2009. Phospholipase D- and phosphatidic acid-mediated signaling in plants. Biochim. Biophys. Acta 179:927-935.

Lohani, S., P.K. Trivedi, and P. Nath. 2004. Changes in activities of cell wall hydrolases during ethylene-induced ripening in banana: Effect of 1-MCP, ABA and IAA. Postharvest Biol. Technol. 31:119-126.

Ludford, P.M. 1987. Postharvest hormone changes in vegetables and fruit, p. 574-592. In: P.J. Davies (ed.). Plant hormones and their role in plant growth and development. Springer, The Netherlands.

Medlicott, A.P., A.J. Semple, A.J. Thompson, H.R. Blackbourne, and A.K. Thompson. 1992. Measurement of colour changes in ripening bananas and mangoes by instrumental, chemical and visual assessments. Trop. Agr. (Trinidad) 69:161-166.
Meijer, H.J.G. and T. Munnik. 2003. Phospholipidbased signaling in plants. Annu. Rev. Plant Biol. 54:265-306.

Ozgen, M., K.M. Farag, S. Ozgen, and J.P. Palta 2005. Lysophosphatidylethanolamine accelerates color development and promotes shelf life of cranberries. HortScience 40:127-130.

Pelayo, C., E.V.B. Vilas Boas, M. Benichou, and A.A. Kader. 2003. Variability in responses of partially ripe bananas to 1-methylcyclopropene. Postharvest Biol. Technol. 28:75-85.

Prasanna, V., T.N. Prabha, and R.N. Tharanathan. 2007. Fruit ripening phenomena-an overview. Crit. Rev. Food Sci. Nutr. 47:1-19.

Purgatto, E., F.M. Lajolo, J.R.O.d. Nascimento, and B.R. Cordenunsi. 2001. Inhibition of $\beta$-amylase activity, starch degradation and sucrose formation by indole-3-acetic acid during banana ripening. Planta 212:823-828.

Reid, M.S. 1992. Ethylene in postharvest technology, p. 97-108. In: A.A. Kader (ed.). Postharvest technology of horticultural crops. 2nd ed. University of California, Division of Agriculture and Natural Resources, publication 3311.

Rhodes, M.J.C. 1970. The cilmacteric ripening of fruit, p. 521-533. In: A.C. Hulme (ed.). Biochemstry of fruit and their products. Academic Press, London, UK.

Ryu, S.B., B.H. Karlsson, M. Özgen, and J.P. Palta. 1997. Inhibition of phospholipase D by lysophosphatidylethanolamine, a lipid-derived senescence retardant. Proc. Natl Acad. Sci. USA 94:12717-12721.

Ryu, S.B. and X. Wang. 1995. Expression of phospholipase D during castor bean leaf senescence. Plant Physiol. Biochem. 108:713-719.

Saltveit, M.E. 2004. Respiratory metabolism. In: The commercial storage of fruits, vegetables, and florist and nursery stocks. Agriculture Handbook, Number 66.

SAS $^{\circledR}$. 2009. SAS online doc. Version 9.2 copyright 2009. SAS Institute Inc., Cary, NC.

Selvaraj, Y. and R. Kumar. 1989. Studies on fruit softening enzymes and polyphenol oxidase activity in ripening mango (Mangifera indica L.) fruit. J. Food Sci. Technol. 26:218-222.

Selvaraj, Y., R. Kumar, and D.K. Pal. 1989 Changes in sugars, organic acids, amino acids, lipid constituents and aroma characteristics of ripening mango (Mangifera indica L.) fruit. J. Food Sci. Technol. 26:308-313.

Serek, M., R.B. Jones, and M.S. Reid. 1994. Role of ethylene in opening and senescence of Gladiolus sp. Flowers. J. Amer. Soc. Hort. Sci. 119:1014-1019.

Seymour, G.B., J.E. Taylor, and G.A. Tucker. 1993. Biochemistry of fruit ripening. Chapman and Hall, New York, NY.

Sisler, E.C. and M. Serek. 1997. Inhibitors of ethylene responses in plants at the receptor level: Recent developments. Physiol. Plant. 100:577-582.

Sisler, E.C., M. Serek, and E. Dupille. 1996. Comparison of cyclopropene, 1-methylcyclopropene, and 3,3-dimethylcyclopropene as ethylene antagonists in plants. Plant Growth Regulat. 18:169-174.

Snider, A., J.P. Palta, and T. Peoples. 2003. The potential use of lysophosphatidylethanolamine (LPE), a natural lipid, to lengthen the vase life of short-lived 'Lavande' and 'sensation' roses. Acta Hort. 624:419-426.

Tapre, A.R. and R.K. Jain. 2012. Study of advanced maturity stages of banana. Intl. J. Adv. Eng. Res. Stud. 1:272-274.

Tucker, G.A. 1993. Introduction, p. 1-51. In: G.B. Seymour, J.E. Taylor, and G.A. Tucker (eds.). Biochemistry of fruit ripening. Chapman and Hall, London, UK.

Tucker, G.A. and D. Grierson. 1987. Fruit ripening, p. 265-319. In: D. Davies (ed.). The biochemistry of plants. Academic Press Inc., New York, NY.

Wade, N.L. and D.G. Bishop. 1978. Changes in the lipid composition of ripening banana fruits and evidence for an associated increase in cell membrane permeability. Biochim. Biophys. Acta Lipids Lipid Metab. 529:454-464.

Wang, X. 2001. Plant phospholipases. Annu. Rev. Plant Physiol. Plant Mol. Biol. 52:211-231.

Wang, X. 2002. Phospholipase D in hormonal and stress sinaling. Curr. Opin. Plant Biol. 5:408-414.

Watkins, C.B. 2006. The use of 1-methylcyclopropene (1-MCP) on fruits and vegetables. Biotechnol. Adv. 24:389-409.

Zhang, M.J., Y.M. Jiang, W.B. Jiang, and X.J. Liu. 2006. Regulation of ethylene synthesis of harvested banana fruit by 1-methylcyclopropene. Food Technol. Biotechnol. 44:111-115. 